Abstracta Iranica Iranica

Revue bibliographique pour le domaine irano-aryen

Volume 32-33 | 2013

Comptes rendus des publications de 2009-2010

\title{
Parvin Loloi. Hâfiz and the Language of Love in Nineteenth-Century English and American Poetry
}

Anna Livia Beelaert

\section{OpenEdition}

1 Journals

Édition électronique

URL : http://journals.openedition.org/abstractairanica/40962

DOI : 10.4000/abstractairanica.40962

ISSN : 1961-960X

\section{Éditeur :}

CNRS (UMR 7528 Mondes iraniens et indiens), Éditions de l'IFRI

\section{Édition imprimée}

Date de publication : 1 décembre 2013

ISSN : 0240-8910

\section{Référence électronique}

Anna Livia Beelaert, « Parvin Loloi. Hāfız and the Language of Love in Nineteenth-Century English and American Poetry », Abstracta Iranica [En ligne], Volume 32-33 | 2013, document 429, mis en ligne le 01 juillet 2016, consulté le 03 octobre 2020. URL : http://journals.openedition.org/abstractairanica/40962 ; DOI : https://doi.org/10.4000/abstractairanica.40962

Ce document a été généré automatiquement le 3 octobre 2020.

Tous droits réservés 


\title{
Parvin Loloi. Hāfiz and the Language of Love in Nineteenth- Century English and American Poetry
}

\author{
Anna Livia Beelaert
}

\section{RÉFÉRENCE}

Parvin Loloi. « Hâafiz and the Language of Love in Nineteenth-Century English and American Poetry ", in : Leonard Lewisohn, ed., Hafiz and The Religion of Love in Classical Persian Poetry. London/New York, I.B. Tauris in association with Iran Heritage Foundation, 2010, p. 279-94.

1 L'A., éminente spécialiste des traductions de Ḥāfez en anglais, qui a publié en 2004 le livre incontournable Hâfiz, Master of Persian Poetry: A Critical Bibliography. English Translations Since the Eighteenth Century, montre ici dans quelle mesure le langage amoureux de Ḥăfez a influencé les poètes romantiques anglais et américains. Un certain nombre d'entre eux ont lu "énormément et avec enthousiasme la littérature de l'Orient" (p. 283), et ils ont eu accès aux poèmes de Ḥăfez en premier lieu par les traductions du célèbre William Jones (1746-1794). L'A. traite quatre poètes en particulier, Byron, Shelley, Emerson et Tennyson, Byron étant le seul à avoir eu une expérience de première main avec l'orient et les milieux soufis. En ce qui concerne Shelley, il a lu Jones, bien sûr, mais la doctrine de l'émanation qui est à la base de sa philosophie de l'amour est tout aussi redevable au néoplatonisme qu'au soufisme. Emerson, quant à lui, avait lu les traductions de Jones déjà dans son adolescence, mais il a connu Ḥâfez aussi par la traduction allemande du Dìvān de Hammer et par le Westöstlicher Divan de Goethe, pour qui cette traduction avait eu l'importance que l'on sait. Pour lui Ḥăfez est "la pierre de touche" et sa poésie celle qui était la plus capable de "vacciner le lecteur avec la folie poétique' (p. 288). Tennyson, finalement, est le seul qui 
a même essayé d'apprendre le persan pour lire le poète dans le texte et pour lui aussi le West-östlicher Divan était une source d'inspiration majeure. Sa poésie montre nombre de traces d'une grande "connaissance du langage ésotérique et érotique de Ḥâfez" (p. 290). L'A. conclut qu'aucun des poètes majeurs de langue anglaise de cette période, excepté Emerson et Tennyson, n'a fait "un usage réellement considérable de la poésie de Ḥăfez dans leur oeuvre personnelle", et qu'aucun des quatre ne peut être comparé avec Goethe, qui est le seul à avoir "recréé Ḥāfez dans une autre tradition poétique" (p. 292).

\section{AUTEURS}

\section{ANNA LIVIA BEELAERT}

Université libre de Bruxelles 